\title{
In situ identification of Legionellaceae using $16 S$ rRNA-targeted oligonucleotide probes and confocal laser scanning microscopy
}

\author{
Werner Manz, ${ }^{1}$ Rudolf Amann, ${ }^{1}$ Regine Szewzyk, ${ }^{2}$ Ulrich Szewzyk, ${ }^{2}$ \\ Thor-Axel Stenström, ${ }^{2}$ Peter Hutzler ${ }^{3}$ and Karl-Heinz Schleifer ${ }^{1}$
}

Author for correspondence: Rudolf Amann. Tel: +49 892105 2373. Fax: +49 8921052360 .
e-mail : amann@mbitum2.biol.chemie.tu-muenchen.de

1 Lehrstuhl für

Mikrobiologie, Technische

Universităt München,

D-80290 Munich, Germany

2 Swedish Institute for Infectious Disease Control, S-10521 Stockholm, Sweden

3 GSF - Forschungszentrum für Umwelt und Gesundheit, Institut for Pathologie und Biomedizinische Bildanalyse, D-85758 Oberschleißheim, Germany

\begin{abstract}
Bacteria of the family Legionellaceae form a monophyletic group within the $\gamma$-subclass of Proteobacteria. Based on comparative sequence analysis we constructed two oligonucleotide probes complementary to regions of $16 \mathrm{~S}$ rRNA characteristic for Legionellaceae. Probe specificities were tested by whole-cell or dot-blot hybridization against 14 serogroups of Legionella pneumophila, 22 different Legionella spp. and 72 non-legionellae reference strains. Using optimized conditions both probes hybridized to all tested strains of L. pneumophila. Probes LEG226 and LEG705 hybridized to $71 \%$ and $90 \%$ of the Legionella species tested, respectively. With the exception of Methylomonas alba none of the non-target strains showed complete sequence homology within the target molecule. In a preliminary evaluation the results of classical techniques employing selective media, immunofluorescence and the probe assay were in good accordance for routine environmental and clinical isolates. L. pneumophila suspended in drinking water at approximately $10^{3}-10^{4}$ c.f.u. $\mathrm{ml}^{-1}$ could be rapidly detected by a combination of membrane filtration on polycarbonate filters and whole-cell hybridization. Even after incubation for 1 year a proportion of the released cells was still detectable. In situ hybridization also facilitated visualization of Legionella spp. cells in model biofilms. A combination of in situ hybridization and confocal laser scanning microscopy (CLSM) was used to analyse the three-dimensional arrangement of L. pneumophila within cells of the ciliated protozoan Tetrahymena pyriformis. Whole-cell probing with 165 rRNA-targeted oligonucleotides could, in the future, complement established techniques like immunofluorescence and PCR in ecological and epidemiological studies of Legionellaceae.
\end{abstract}

Keywords: in situ hybridization, rRNA-targeted oligonucleotide probes, Legionellaceae, confocal laser scanning microscopy

\section{INTRODUCTION}

Legionellaceae are ubiquitous environmental microorganisms which can cause severe illnesses including 'Legionnaires' disease' (Brenner et al., 1979). They are found both in natural and man-made environments, such as cooling-towers (Dondero et al., 1980; States et al., 1990; Colbourne \& Dennis, 1989). Some 39 species of the genus Legionella (Dennis et al., 1993) and 14 distinct

Abbreviations: CLSM, confocal laser scanning microscopy; TRITC, tetramethylrhodamine-5-isothiocyanate. serogroups of the species Legionella pneumophila have been described to date. These form a monophyletic group within the $\gamma$-subclass of Proteobacteria (Schleifer \& Ludwig, 1989; Ludwig \& Stackebrandt, 1983; Fry et al., 1991b).

Nosocomial legionellosis has been frequently related to contaminated potable water supplies. However, isolation and cultural recovery of $L$. pneumophila on selective media is often hampered by the presence of faster growing organisms and the ability of Legionellaceae to form viable but nonculturable cells (Hussong et al., 1987; PaszkoKolva et al., 1992). Cultivation of L. pneumophila has 
proven difficult, especially after exposure to biocides and disinfecting agents like hypochlorite (England et al., 1982; Bej et al., 1991).

Legionellae are able to infect free-living amoebae and ciliated protozoa in vitro (Fields et al., 1984) as well as in natural environments (Barbaree et al., 1986; Winn, 1988). Intracellular growth of L. pneumopbila in trophozoites of a variety of amoebae has been shown under laboratory conditions (Kurtz et al., 1982). Consequently, the amoebae species naturally occurring in water could serve as a sort of intermediate host, significantly enhancing the survival of Legionella spp. in oligotrophic aquatic habitats. Furthermore, a specific association with free-living amoebae has been used to isolate Legionellaceae from clinical and environmental samples (Fields et al., 1989; Rowbotham, 1983; Fallon \& Rowbotham, 1990; Fry et al., 1991a).

Due to slow growth and lack of suitable phenotypic tests, identification of Legionella spp. by classical techniques remains difficult. To circumvent these limitations, antibody techniques (Edelstein et al., 1985; Gosting et al., 1984), DNA hybridization assays (Grimont et al., 1985), commercial DNA probes complementary to $16 \mathrm{~S}$ rRNA (Gen-Probe) as well as PCR assays (Mahbubani et al., 1990; Koide et al., 1993; Starnbach et al., 1989) have been developed. The target is in most cases the clinically important species L. pneumophila.

Fluorescently labelled, rRNA-targeted oligonucleotide probes are a newly available alternative for in situ detection and identification of individual microbial cells (DeLong $e t$ al., 1989; Amann et al., 1990a, b; Manz et al., 1993; Wagner et al., 1993). They have successfully been used for the identification of hitherto uncultured bacterial endosymbionts in protozoa, e.g. intranuclear symbionts of the genus Holospora spp. in the ciliate Paramecium caudatum (Amann et al., 1991) and the legionella-related parasite Sarcobium lyticum in small amoebae (Springer et al., 1992). The development and application of oligonucleotide probes specific for the family Legionellaceae should not only facilitate determinative studies but also yield tools for investigations on the spatial and temporal distribution of this important group of micro-organisms.

\section{METHODS}

Strains and cultivation. Bacterial strains and sources used in this study are listed in Tables 1 and 2. Legionella strains were obtained from the American Type Culture Collection (ATCC; Rockville, Maryland, USA) or are held in the culture collection of the Legionella reference unit of the Swedish Institute for Infectious Disease Control (SMI, Stockholm, Sweden). Legionella strains were cultured on BCYE agar at $37^{\circ} \mathrm{C}$ for 2-3 d. Non-legionellae reference strains were cultured following the recommendations of the catalogue of the ATCC. Isolates from tap water samples were cultivated on yeast-peptone agar (yeast extract, $0.6 \%$; peptone, $0.3 \%$; agar, $1.5 \%$, w/v).

Cell fixation. Legionellae were harvested from plates, carefully suspended in sterile PBS at pH 7.4 (PBS: $130 \mathrm{mM} \mathrm{NaCl}, 10 \mathrm{mM}$ $\left.\mathrm{Na}_{2} \mathrm{HPO}_{4} / \mathrm{NaH}_{2} \mathrm{PO}_{4}\right)$ and fixed for at least $3 \mathrm{~h}$ by adding 3 vols $4 \%(\mathrm{w} / \mathrm{v})$ paraformaldehyde solution. After washing once with PBS cells were stored in a 1:1 mixture of PBS and $96 \%(\mathrm{v} / \mathrm{v})$ ethanol at $-20{ }^{\circ} \mathrm{C}$. Fixed cells were spotted on precleaned, gelatin coated $\left[0.01 \% \mathrm{KCr}\left(\mathrm{SO}_{4}\right)_{2}, 0.1 \%\right.$ gelatin] microscopic slides (Paul Marienfeld KG, Bad Mergentheim, Germany), airdried and dehydrated in 50, 80 and $96 \%(\mathrm{v} / \mathrm{v})$ ethanol $(3 \mathrm{~min}$ each).

Oligonucleotide probes. The two probes LEG226 and LEG705 have been developed based on a comparative analysis of about 30 aligned 16S rRNA sequences of Legionellaceae (Fry et al., 1991b) as described by Amann et al. (1990a) and Stahl \& Amann (1991), and are complementary to regions of the $16 \mathrm{~S}$ rRNA of most members of the family Legionellaceae. The probe EUB338, complementary to a region of the 16S rRNA conserved in the domain Bacteria (Amann et al., 1990b), was used as a positive control. Probe ALF1b, complementary to members of the $\alpha$-subclass of Proteobacteria (Manz et al., 1992), was used for biofilm studies. Probe sequences and target positions are listed in Table 3.

Oligonucleotides were synthesized with a C6-TFA aminolinker [6-(trifluoroacetylamino)-hexyl-(2-cyanoethyl)-( $N, N$-diisopropyl)-phosphoramidite] at the 5'-end (MWG Biotech). Labelling with tetramethylrhodamine-5-isothiocyanate (TRITC; Molecular Probes) or 5(6)-carboxyfluorescein-N-hydroxysuccinimide-ester (FLUOS, Boehringer Mannheim) was performed as described previously (Amann et al., 1990a). For dot-blot hybridizations the probes were labelled with digoxigenin following the protocols of Zarda et al. (1991).

Nucleic acid extraction and dot-blot hybridization. For isolation of nucleic acids from Legionella spp., cells were transferred into $200 \mu$ lysozyme solution $\left(2 \mathrm{mg} \mathrm{ml}^{-1}\right)$, carefully mixed and incubated for $15 \mathrm{~min}$ at $37^{\circ} \mathrm{C}$. For cell lysis $200 \mu \mathrm{l}$ guanidium thiocyanate buffer $(5 \mathrm{M}$ guanidine thiocyanate, $0 \cdot 1 \mathrm{M}$ EDTA, $0.5 \%, \mathrm{v} / \mathrm{v}, \mathrm{N}$-lauroylsarcosine, $\mathrm{pH} 8.0$ ) was added. After precipitation of proteins with $150 \mu \mathrm{l} 2.5 \mathrm{M}$ ammonium acetate $(\mathrm{pH} 4.5) 550 \mu \mathrm{l}$ chloroform/isoamylalcohol $(24: 1, \mathrm{v} / \mathrm{v})$ was added. After vigorous mixing for $30 \mathrm{~s}$ and centrifugation (15 $\mathrm{min}, 14000 \mathrm{~g}, 5 \mathrm{~min}$ ), the aqueous phase was collected and the nucleic acids precipitated with 2 vols ice-cold ethanol $\left(30 \mathrm{~min},-20^{\circ} \mathrm{C}\right)$. The mixture was centrifuged $(15 \mathrm{~min}$, $14000 \mathrm{~g}$ ) and the pellet was dried and resuspended in doubledistilled water. Nucleic acid isolation from reference strains, immobilization of nucleic acids on nylon membranes and probing with digoxigenin-labelled oligonucleotides were done as described previously (Manz et al., 1992).

Whole-cell hybridization. Whole-cell hybridizations on glass slides were performed as described by Manz et al. (1992). For evaluation of the combination of whole-cell hybridization and membrane filtration $1000 \mathrm{ml}$ potable water was inoculated with approximately $10^{4}$ c.f.u. $\mathrm{ml}^{-1}$ L. pneumophila and aliquots of $50 \mathrm{ml}$ were filtered through a $13-\mathrm{mm}$-diameter, $0 \cdot 2-\mu \mathrm{m}$-pore-size polycarbonate filter using a $50 \mathrm{ml}$ plastic syringe. Filters were then overlaid with $4 \%(\mathrm{w} / \mathrm{v})$ paraformaldehyde solution for $30 \mathrm{~min}$, washed twice with $10 \mathrm{ml}$ PBS, and then dehydrated through a 50,80 and $96 \%(\mathrm{v} / \mathrm{v})$ ethanol series. A $100 \mu \mathrm{l}$ aliquot of hybridization buffer $(20 \%, v / v$, formamide, $0.9 \mathrm{M} \mathrm{NaCl}$, $0.01 \%$ SDS, $20 \mathrm{mM}$ Tris $/ \mathrm{HCl}, \mathrm{pH} \mathrm{7.6)}$ was applied to a glass slide and a single filter was placed on it. For whole-cell hybridization aliquots of $20 \mu \mathrm{l}$ hybridization buffer containing $100 \mathrm{ng}$ of the labelled probe were spotted onto the filters and incubated for $1.5 \mathrm{~h}$ at $46^{\circ} \mathrm{C}$ in a moisture chamber. The filters were removed gently from the slide, transferred into plastic jars filled with washing buffer at $\mathrm{pH} 7 \cdot 2(20 \mathrm{mM}$ Tris $/ \mathrm{HCl}, 180 \mathrm{mM}$ $\mathrm{NaCl}, 0.01 \% \mathrm{SDS}$ ) and incubated for $15 \mathrm{~min}$ at $46^{\circ} \mathrm{C}$. Finally, the filters were removed from the jars, washed once with distilled water and mounted with Citifluor.

In an additional experiment $L$. pneumophila serogroup 1 strain $56 / 1$ (SMI culture collection) was inoculated into $500 \mathrm{ml}$ 
Table 1. Reference strains used for dot-blot analysis

\begin{tabular}{|c|c|}
\hline Name & Origin* \\
\hline Acinetobacter calcoaceticus & LMG $1046^{\mathrm{T}}$ \\
\hline Aeromonas bydrophila & WS 1406 \\
\hline Agrobacterium tumefaciens & ATCC $23308^{\mathrm{T}}$ \\
\hline Alcaligenes eutropbus & DSM $531^{\mathbf{T}}$ \\
\hline Alcaligenes faecalis & ATCC $8750^{\mathrm{T}}$ \\
\hline Alteromonas putrefaciens & DSM 50426 \\
\hline Aquaspirillum metamorphum & DSM $1837^{\mathbf{T}}$ \\
\hline Azospirillum amazonense & DSM $2787^{\mathbf{T}}$ \\
\hline Azospirillum brasilense & DSM $1690^{T}$ \\
\hline Azospirillum balopraeferens & DSM $3675^{\mathrm{T}}$ \\
\hline Bacillus cereus & DSM $31^{\mathrm{T}}$ \\
\hline Bacillus subtilis & ATCC 6633 \\
\hline Brevibacterium ketoglutamicum & DSM 20165 \\
\hline Burkbolderia cepacia & DSM 50181 \\
\hline Chromobacterium violaceum & DSM $30191^{T}$ \\
\hline Clostridium acetobutylicum & NCIMB $8052^{\mathrm{T}}$ \\
\hline Clostridium stercorarium & NCIMB $11754^{\mathrm{T}}$ \\
\hline Comamonas testosteroni & LMG $1800^{T}$ \\
\hline Corynebacterium glutamicum & DSM $20300^{T}$ \\
\hline Cytophaga butchinsonii & LMG 10844 \\
\hline Cytopbaga jobnsonae & LMG 1342 \\
\hline Enterobacter aerogenes & WS 1292 \\
\hline Enterobacter cloacae & WS 1293 \\
\hline Enterococcus cecorum & LMG $11741^{\mathbf{T}}$ \\
\hline Enterococcus dispar & DSM $6630^{\mathrm{T}}$ \\
\hline Enterococcus faecalis & DSM $20478^{\mathrm{T}}$ \\
\hline Enterococcus faecium & DSM $20477^{\mathrm{T}}$ \\
\hline Enterococcus gallinarum & LMG $11207^{\mathrm{T}}$ \\
\hline Enterococcus birae & LMG $6399^{\mathrm{T}}$ \\
\hline Enterococcus malodoratus & LMG $10747^{\mathrm{T}}$ \\
\hline Enterococcus mundtii & LMG $10748^{\mathbf{T}}$ \\
\hline Enterococcus saccharolyticus & LMG $11427^{\mathbf{T}}$ \\
\hline Erwinia carotovora & WS 1394 \\
\hline Escherichia coli & $\operatorname{DSM} 30083^{T}$ \\
\hline Flavobacterium breve & LMG $4011^{\mathrm{T}}$ \\
\hline Flavobacterium ferrugineum & LMG $4021^{\mathrm{T}}$ \\
\hline Flavobacterium gleum & LMG 8334 \\
\hline Flavobacterium indologenes & LMG 8336 \\
\hline Flavobacterium odoratum & LMG 4028 \\
\hline Flavobacterium uliginosum & LMG $3809^{T}$ \\
\hline Haliscomenobacter bydrossis & DSM 1100 \\
\hline Lactobacillus casei & LMG 9091 \\
\hline Lactococcus cremoris & DSM $20069^{T}$ \\
\hline Lactococcus lactis & DSM $20481^{\mathrm{T}}$ \\
\hline Leucothrix mucor & $\operatorname{DSM} 2157^{\mathrm{T}}$ \\
\hline Magnetospirillum gryphiswaldense & DSM $6361^{T}$ \\
\hline Micrococcus luteus & $\operatorname{CCM~} 169^{\mathrm{T}}$ \\
\hline Moraxella anatipestifer & LMG 11602 \\
\hline Myxococcus fulvus & GBF Mx-f2 \\
\hline Myxococcus virescens & GBF Mx-v4 \\
\hline Nocardioides simplex & DSM $20130^{T}$ \\
\hline Paracoccus denitrificans & $\mathrm{DSM} 65^{\mathrm{T}}$ \\
\hline Pectinatus frisingensis & DSM 20465 \\
\hline Proteus vulgaris & WS 1356 \\
\hline Pseudomonas alcaligenes & DSM $50342^{T}$ \\
\hline Pseudomonas fuorescens & DSM 50090 \\
\hline Pseudomonas pseudoalcaligenes & LMG $1225^{\mathrm{T}}$ \\
\hline
\end{tabular}

$\begin{array}{ll}\text { Pseudomonas putida } & \text { DSM } 291^{\mathrm{T}} \\ \text { Pseudomonas stutzeri } & \text { DSM } 50227 \\ \text { Rhodobacter capsulatus } & \text { DSM } 1710^{\mathrm{T}} \\ \text { Rhodococcus rhodochrous } & \text { DSM } 43008 \\ \text { Rhodospirillum rubrum } & \text { DSM } 107 \\ \text { Saprospira grandis } & \text { LMG } 10407^{\mathrm{T}} \\ \text { Serratia marcescens } & \text { WS } 1359 \\ \text { Sphaerotilus natans } & \text { ATCC } 13338^{\mathrm{T}} \\ \text { Sphingobacterium mizutae } & \text { LMG } 8340^{\mathrm{T}} \\ \text { Sphingobacterium spiritivorum } & \text { LMG } 8347^{\mathrm{T}} \\ \text { Staphylococcus aureus } & \text { DSM } 20231^{\mathrm{T}} \\ \text { Streptococcus salivarius } & \text { DSM } 20560^{\mathrm{T}} \\ \text { Thiobacillus acidophilus } & \text { DSM } 700^{\mathrm{T}} \\ \text { Weeksella virosa } & \text { LMG } 8349 \\ \text { Weeksella zoobelcum } & \text { LMG } 8352\end{array}$

*T, Type strain; ATCC, American Type Culture Collection, Rockville, MD, USA; CCM, Czechoslovak Collection of Microorganisms, Brno, CSFR; DSM, Deutsche Sammlung von Mikroorganismen und Zellkulturen, Braunschweig, Germany; GBF, Gesellschaft für Biotechnologische Forschung, Braunschweig, Germany; LMG, Laboratorium voor Microbiologie, Universiteit Gent, Belgium; NCIMB, The National Collections of Industrial and Marine Bacteria, Torry Research Station, Aberdeen, Scotland, UK; WS, Collection of the Institut für Mikrobiologie, Forschungszentrum für Milch- und Lebensmittel, Technical University Munich, Freising Weihenstephan, FRG.

autoclaved, filter-sterilized drinking water to achieve an initial concentration of $5 \times 10^{3}$ c.f.u. $\mathrm{ml}^{-1}$. After 1 year of incubation at $30^{\circ} \mathrm{C}$ cells were harvested by centrifugation $(5000 \mathrm{~g}, 20 \mathrm{~min})$, resuspended in $10 \mathrm{ml}$ autoclaved, filter-sterilized drinking water, fixed for $3 \mathrm{~h}$ with $4 \%(\mathrm{w} / \mathrm{v})$ paraformaldehyde solution and hybridized with TRITC-labelled probe LEG 705.

In situ detection of $L$. pneumophila in model biofilms. A model biofilm of a water bacterium identified as Spbingomonas paucimobilis by API $20 \mathrm{NE}$ (Analytab Products) was generated using a down-flow fixed-bed reactor as described recently (Szewzyk et al., 1994). After $2 \mathrm{~d}$, established biofilms were transferred to a continuous flow unit and inoculated with low numbers $\left(10^{2}-10^{3}\right.$ c.f.u. $\left.\mathrm{ml}^{-1}\right)$ of $L$. pneumophila serogroup 1 strain 56/1 (SMI culture collection). One hour after inoculation continuous flow was started to remove unattached $L$. pneumopbila cells. The glass slides were removed after 8,12 and $24 \mathrm{~h}$ incubation and subsequently used for in situ hybridization (Manz et al., 1993).

In situ hybridization of $L$. pneumophila within fixed cells of Tetrahymena pyriformis. T. pyriformis was grown on synthetic freshwater medium (Szewzyk et al., 1994) at $32{ }^{\circ} \mathrm{C}$ supplemented with heat-killed Escherichia coli as food bacteria. Cells of a water isolate of L. pneumopbila serogroup 1 (strain SJ 56/1, SMI culture collection) were added at concentrations of $10^{6}$ or $10^{8}$ cells $\mathrm{ml}^{-1}$, respectively. After $3 \mathrm{~d}$ incubation $\left(37^{\circ} \mathrm{C}\right)$ cells of $T$. pyriformis were transferred onto sterile glass slides and air-dried. Finally, slides containing cells of $T$. pyriformis were fixed for $1 \mathrm{~h}$ in $4 \%(\mathrm{w} / \mathrm{v})$ aqueous paraformaldehyde solution, washed once in PBS and dehydrated in an aqueous ethanol series $(50 \%, 80 \%$, $96 \%, v / v)$. For in situ hybridization aliquots of $20 \mu \mathrm{l}$ hybridization buffer $(20 \%$, v/v, formamide, $0.9 \mathrm{M} \mathrm{NaCl}, 0.01 \%$ SDS, $20 \mathrm{mM}$ Tris $/ \mathrm{HCl}, \mathrm{pH} \mathrm{7.6)}$ containing $100 \mathrm{ng}$ of the labelled probe were dotted onto the slides followed by hybridization for $1.5 \mathrm{~h}$ at $46^{\circ} \mathrm{C}$ in a moisture chamber. The probe was removed gently with washing buffer $(20 \mathrm{mM}$ Tris/ $\mathrm{HCl}, \mathrm{pH} 7 \cdot 6,180 \mathrm{mM} \mathrm{NaCl}, 0.01 \% \mathrm{SDS}$ ), and the cells 
Table 2. Legionella strains used for whole-cell and dot-blot hybridizations

\begin{tabular}{|c|c|c|c|}
\hline \multirow[t]{2}{*}{ Name } & \multirow[t]{2}{*}{ Origin* } & \multicolumn{2}{|c|}{$\begin{array}{c}\text { Reaction with } \\
\text { probe } \dagger\end{array}$} \\
\hline & & LEG226 & LEG705 \\
\hline Legionella pneumopbila sg 1 & ATCC $33152^{\mathrm{T}}$ & + & + \\
\hline Legionella pneumopbila sg 2 & ATCC 33154 & + & + \\
\hline Legionella pneumophila sg 3 & ATCC 33155 & + & + \\
\hline Legionella pneumophila sg 4 & ATCC 33156 & + & + \\
\hline Legionella pneumophila sg 5 & ATCC 33216 & + & + \\
\hline Legionella pneumophila sg 6 & ATCC 33215 & + & + \\
\hline Legionella pneumophila sg 7 & ATCC 33823 & + & + \\
\hline Legionella pneumophila sg 8 & ATCC 35096 & + & + \\
\hline Legionella pneumopbila sg 9 & ATCC 35289 & + & + \\
\hline Legionella pneumopbila sg 10 & ATCC 35283 & + & + \\
\hline Legionella pneumopbila sg 11 & ATCC 43130 & + & + \\
\hline Legionella pneumophila sg 12 & ATCC 43290 & + & + \\
\hline Legionella pneumopbila sg 13 & ATCC 43736 & + & + \\
\hline Legionella pneumopbila sg 14 & ATCC 43703 & + & + \\
\hline Legionella anisa & ATCC $35292^{\mathrm{T}}$ & + & + \\
\hline Legionella bozemanii sg 1 & ATCC $33217^{\mathrm{T}}$ & + & + \\
\hline Legionella bozemanii sg 2 & ATCC 35545 & + & + \\
\hline Legionella cicinnatiensis & ATCC $43753^{\mathrm{T}}$ & + & + \\
\hline Legionella dumoffii & ATCC $33279^{\mathrm{T}}$ & + & + \\
\hline Legionella erytbra & ATCC $35303^{\mathrm{T}}$ & + & + \\
\hline Legionella feeleii & ATCC $35072^{\mathrm{T}}$ & + & + \\
\hline Legionella gormanii & ATCC $33297^{\mathrm{T}}$ & + & + \\
\hline Legionella backeliae & ATCC $35250^{\mathrm{T}}$ & + & + \\
\hline Legionella backeliae & ATCC 35999 & + & + \\
\hline Legionella jordanis & ATCC $33623^{\mathrm{T}}$ & + & + \\
\hline Legionella longbeachae sg 1 & ATCC $33462^{\mathrm{T}}$ & + & + \\
\hline Legionella micdadei Tatlock & ATCC $33218^{\mathrm{T}}$ & + & + \\
\hline Legionella rubrilucens & ATCC $35304^{\mathrm{T}}$ & + & + \\
\hline Legionella sainthelensi & ATCC $35248^{\mathrm{T}}$ & + & + \\
\hline Legionella spiritensis & ATCC $35249^{\mathrm{T}}$ & + & + \\
\hline Legionella tucsonensis & ATCC $49180^{\mathrm{T}}$ & + & + \\
\hline Legionella wadswortbii & ATCC $33877^{\mathrm{T}}$ & + & + \\
\hline Legionella birminghamensis & ATCC $43702^{\mathrm{T}}$ & - & + \\
\hline Legionella feeleii & ATCC 35849 & - & + \\
\hline Legionella oakridgensis & ATCC $33761^{\mathbf{T}}$ & - & + \\
\hline Legionella israelensis & ATCC $43119^{\mathrm{T}}$ & - & + \\
\hline Legionella parisiensis & ATCC $35299^{\mathrm{T}}$ & - & - \\
\hline Legionella quinlivanii & ATCC $43830^{\mathrm{T}}$ & - & - \\
\hline
\end{tabular}

${ }^{*} \mathrm{~T}$, Type strain.

$\dagger+$, Strong hybridization signal; - , no hybridization signal.

were overlaid with $500 \mu \mathrm{l}$ washing buffer and incubated in a moisture chamber for $15 \mathrm{~min}$ at $46^{\circ} \mathrm{C}$. Finally, the slides were carefully rinsed with distilled water, air-dried, and mounted in Citifluor.

Microscopy and documentation. Probe-conferred fluorescence was detected with Zeiss Axioplan and Zeiss Axioskop microscopes fitted for epifluorescence microscopy with $50 \mathrm{~W}$ highpressure bulbs and Zeiss filter sets 01,09 and 15. Colour- micrographs were taken with Fuji P 1600 and Kodak EES 1600 colour reversal film. Exposure times were 2-8 s for epifluorescence micrographs and $0.01-0.03 \mathrm{~s}$ for phase contrast. Alternatively, confocal epifluorescence laser scanning microscopy was done on a Carl Zeiss LSM 410 using an excitation wavelength of $543 \mathrm{~nm}$. A series of 24 confocal sections were scanned with increments of $0.5 \mu \mathrm{m}$. Image processing and threedimensional reconstructions were performed using the standard software package delivered with the instrument. 
Table 3. Probe sequences, target sites and formamide concentration in the hybridization buffer required for specific in situ hybridization

\begin{tabular}{|c|c|c|c|}
\hline Probe & Sequence & Target site* & $\begin{array}{c}\text { Formamide } \\
(\%)\end{array}$ \\
\hline LEG226 & 5'-TCGGACGCAGGCTAATCT-3' & $16 \mathrm{~S}, 226-243$ & 20 \\
\hline LEG705 & 5'-CTGGTGTTCCTTCCGATC-3' & $16 \mathrm{~S}, 705-722$ & 20 \\
\hline EUB338 & 5'-GCTGCCTCCCGTAGGAGT-3' & $16 \mathrm{~S}, 338-355$ & 0 \\
\hline Alf1b & $5^{\prime}$-CGTTCG(C/T)TCTGAGCCAG-3' & $16 \mathrm{~S}, \quad 19-35$ & 20 \\
\hline
\end{tabular}

* E. coli numbering (Brosius et al., 1981).

(a)
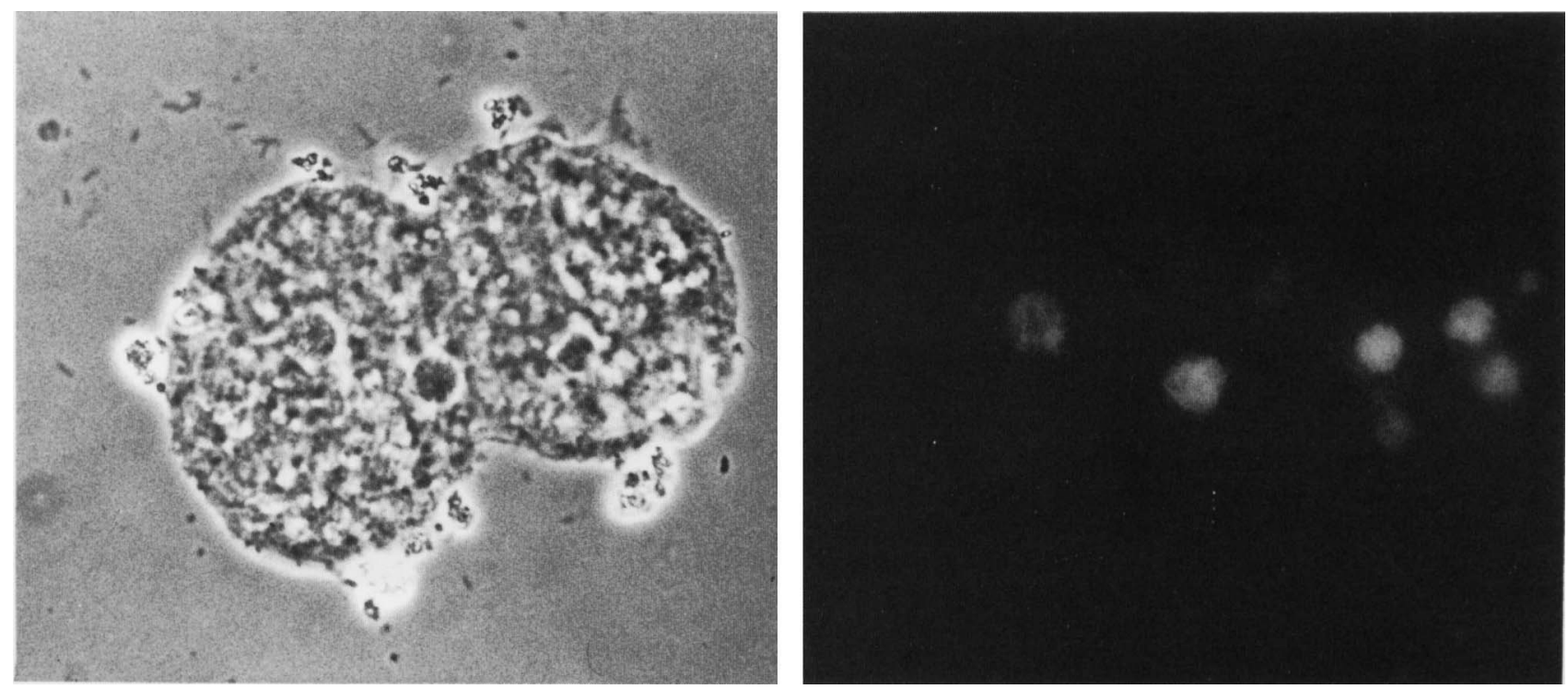

(b)
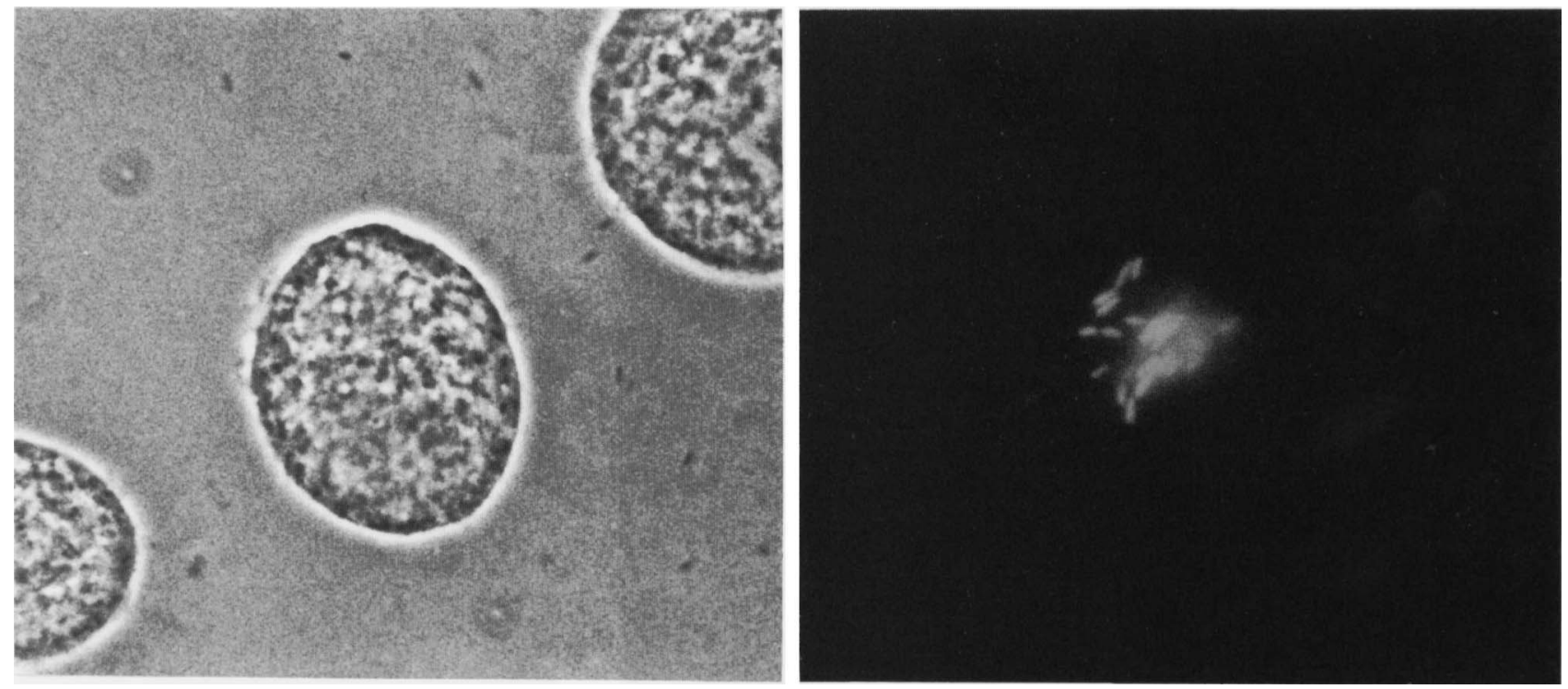

Fig. 1. In situ hybridization of infected $T$. pyriformis cells with TRITC-labelled probe LEG705. Phase-contrast (left) and epifluorescence micrographs (right) are shown for identical microscopic fields. All photomicrographs were done at a magnification of $\times 1000$. (a) Cells of $L$. pneumophila are arranged within vacuoles of $T$. pyriformis; (b) cells of $L$. pneumophila being released from a former vacuole in the process of colonizing the protoplasm. 


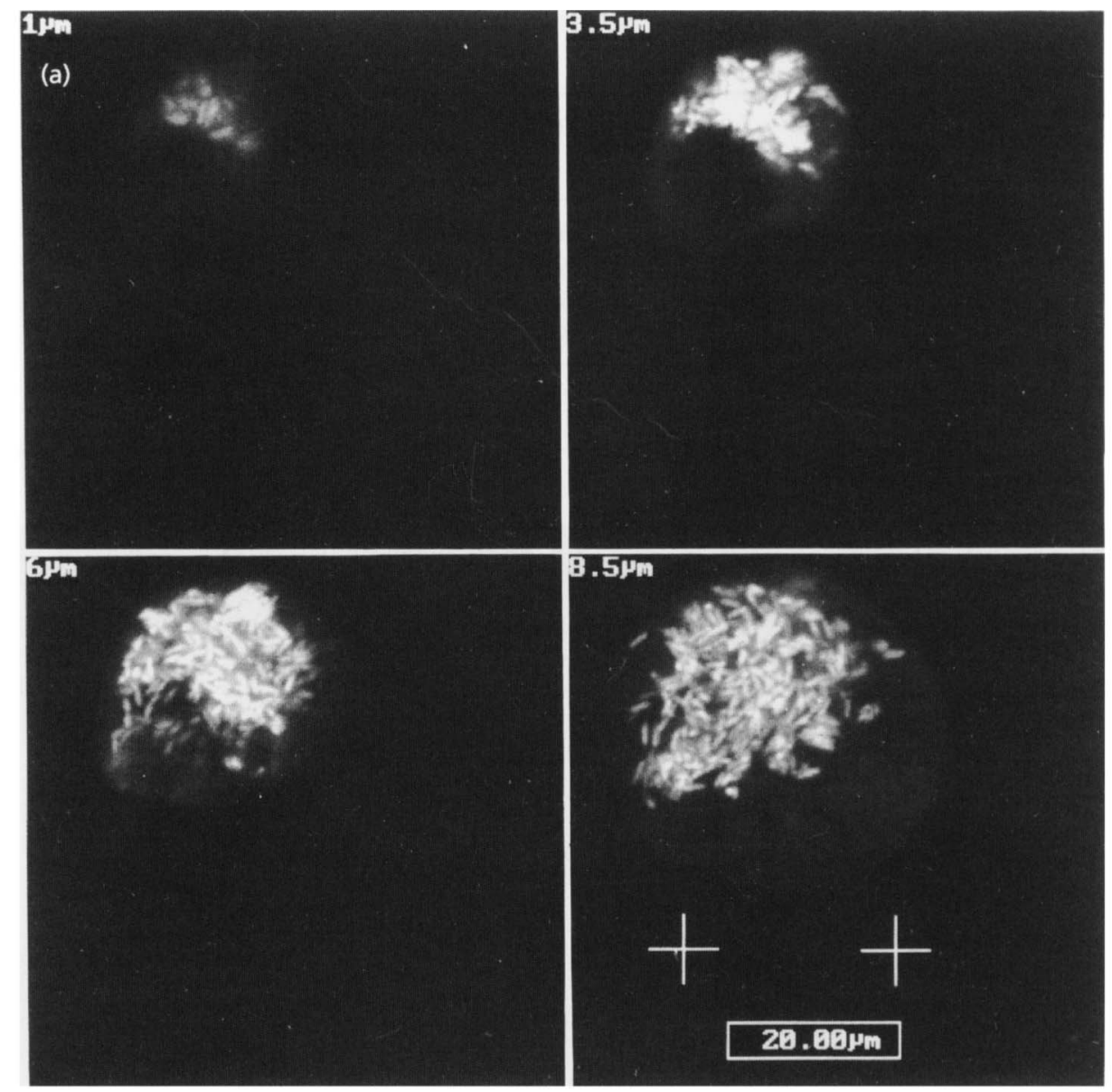

(b)

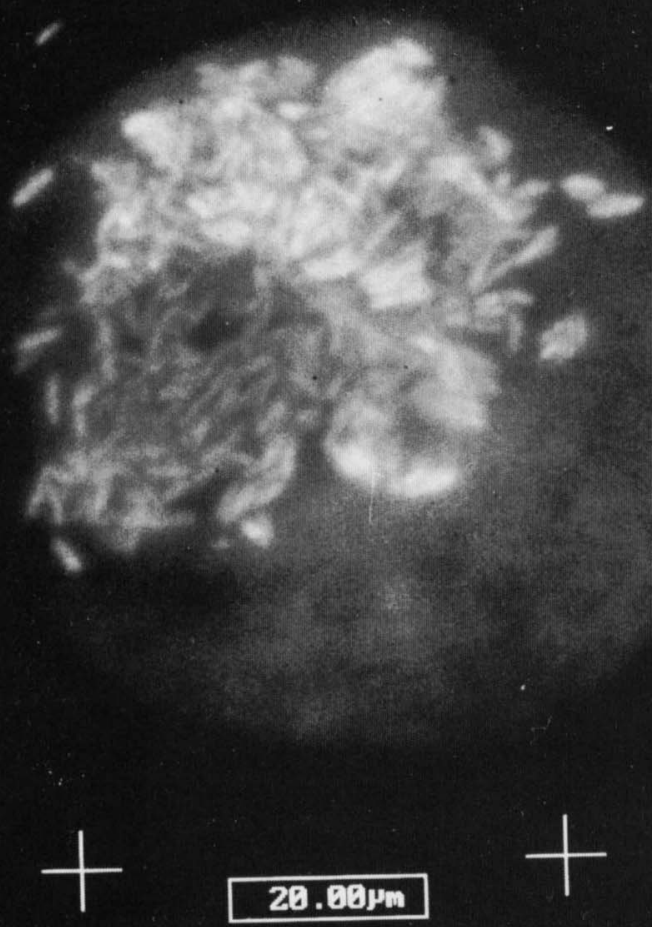

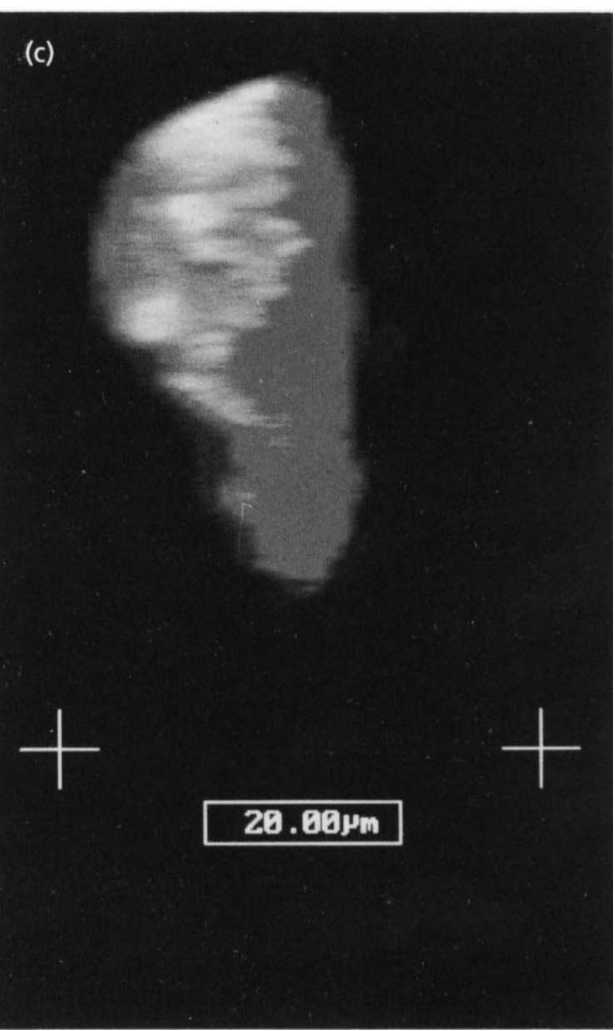




\section{RESULTS}

\section{Probe specificities}

The probes specific for the family Legionellaceae (Table 3) were designed based on comparative analysis of about 30 complete or almost complete $16 \mathrm{~S}$ rRNA-sequences of Legionellaceae (Fry et al., 1991b) and furthermore approximately 1500 sequences of other bacteria (Larsen et al., 1993; Neef et al., 1993). With the exception of the $16 \mathrm{~S}$ rRNA sequence of Metbylomonas alba, which is complementary to probe LEG705, the probes LEG226 and LEG705 were complementary only to the target regions on the 16S rRNA sequences of members of the Legionellaceae and the legionella-related intracellular parasite Sarcobium lyticum (Springer et al., 1992). All of the other available $16 \mathrm{~S}$ rRNA sequences in the databases showed at least one mismatch. As we could demonstrate previously (Amann et al., 1990a; Manz et al., 1992) oligonucleotide probes can distinguish between complementary and nearly complementary sequences on the basis of a single mismatch.

Since $16 \mathrm{~S}$ rRNA sequences have only been determined for a fraction of the described bacterial species probe specificities were further evaluated by dot-blot analysis against 72 non-legionellae reference strains (Table 1) and 22 different species of Legionella (Table 2). The optimal hybridization stringencies were determined by gradually increasing (in $5 \%$ intervals) the formamide concentration in the hybridization buffer while holding ionic strength $(0.9 \mathrm{M} \mathrm{NaCl})$ and hybridization temperature $\left(46^{\circ} \mathrm{C}\right)$ constant. At $20 \%$ (v/v) formamide probes LEG705 and LEG226 hybridized to all tested strains of $L$. pneumophila and most of the Legionella spp. Whereas probe LEG705 hybridized to all legionellae except for $L$. parisiensis and $L$. quinlivanii (Table 2), probe LEG226 has a somewhat narrower specificity and additionally failed to detect $L$. israelensis, L. oakridgensis, L. birminghamensis and one of two tested strains of $L$. feeleii. No false-positive hybridizations with the reference strains (Table 1) occurred. The immobilization of nucleic acids to the membranes was checked by hybridization with the positive control EUB338 (Amann et al., 1990a); there were positive hybridization signals with all immobilized nucleic acids.

Whole-cell hybridization with probe LEG705 allowed the differentiation of Legionella spp. from reference strains like E. coli even at low stringency conditions (i.e. without addition of formamide). Nevertheless, to assure the specificities determined with the dot blots, whole-cell hybridizations were performed at a formamide concentration of $20 \%$. Whereas good signal strength and specificity was found for LEG705 under these conditions, probe LEG226 yielded weaker fluorescent signals. Therefore, probe LEG705 was used for all whole-cell hybridizations.

\section{Rapid determination of environmental and clinical isolates by whole-cell hybridization}

To evaluate the usefulness and practicability of the wholecell hybridization assay, 130 isolates obtained on BCYE agar inoculated with environmental and clinical samples were examined. Within a collection of 59 isolates which were considered to be members of Legionellaceae by an immunofluorescence assay, 58 isolates showed strong hybridization signals when hybridized with probe LEG705. Further testing of the non-reacting isolate revealed physiological properties uncommon to legionellae. Testing of the 59 isolates by in situ whole-cell hybridizations could be performed within 1 working day.

\section{Whole-cell hybridization on membrane filters}

Membrane filtration is a standard technique to quantify microbial cells in water samples. Cells of $L$. pneumopbila collected from tap water samples seeded with approximately $10^{3}-10^{4}$ c.f.u. $\mathrm{ml}^{-1}$ were readily visualized on the polycarbonate filters by hybridization with the TRITClabelled probe LEG705. When filters were mounted in immersion oil or distilled water probe-conferred fluorescence faded very rapidly, whereas mounting in Citifluor strongly decreased photobleaching and allowed microscopy evaluation even after $48 \mathrm{~h}$.

\section{Whole-cell hybridization of starved cells of $L$. pneumophila}

Cells of L. pneumophila strain 56/1 could not be cultivated on BCYE agar after 1 year of incubation in sterile drinking water at $30^{\circ} \mathrm{C}$. However, hybridization with probe LEG705 demonstrated the presence of Legionella cells. Approximately one third of the cells detected by phase contrast microscopy showed detectable levels of probe-conferred fluorescence after hybridization with probe LEG705.

\section{In situ identification of $L$. pneumophila in model biofilms}

One important advantage of fluorescently labelled oligonucleotide probes is their potential for in situ visualization of the respective target populations. They have already successfully been used to detect sulfate-reducing bacteria

Fig. 2. Confocal fluorescence micrographs of infected $T$. pyriformis cells hybridized with TRITC-labelled probe LEG705. Twenty-four confocal sections were scanned along the optical axis with increments of $0.5 \mu \mathrm{m}$. (a) Collection of four typical optical sections taken at depths of $1 \mu \mathrm{m}, 3.5 \mu \mathrm{m}, 6 \mu \mathrm{m}$ and $8.5 \mu \mathrm{m}$ showing individual cells of $L$. pneumophila within the host cell. (b) Transparent projection of all 24 confocal sections scanned in distances of $0.5 \mu \mathrm{m}$ resulting in an extended focus image of the Legionella cell cluster within T. pyriformis. (c) Interpolated projection perpendicular to image (b) showing the three-dimensional intracellular arrangement of $L$. pneumophila cells within $T$. pyriformis. 
in complex multispecies biofilms (Amann et al., 1990b; Ramsing et al., 1994) and for the detection of E. coli in a model biofilm formed by an aquatic isolate (Szewzyk et al., 1994). In a similar experiment biofilms formed by $S$. paucimobilis were examined for attachment and growth of L. pneumopbila after 8,12 and $24 \mathrm{~h}$ of incubation. As expected, probe LEG705 facilitated in situ monitoring of L. pneumophila (data not shown). Legionellae did attach to the model biofilm and could be detected after $12 \mathrm{~h}$; in this time the volume of the continuous flow unit had been exchanged 40 times. Further studies will examine the potential of legionellae to survive and multiply in such biofilms.

\section{In situ hybridization of infected cells of $T$. pyriformis}

It has been reported that Legionellaceae are able to infect and proliferate within various types of protozoa (Fry et al., 1991a) including T. pyriformis (Fields et al., 1984). In situ hybridization of infected Tetrabymena cells with probe LEG705 visualized by epifluorescence microscopy corroborated these findings. With $10^{8}$ c.f.u. $\mathrm{ml}^{-1}$ of $L$. pneumopbila as inoculum, the cells were tightly packed in certain areas, probably phagosomes, within T. pyriformis (Fig. 1a). However, some cells of L. pneumophila appeared to be spread over the host cell in the experiments with $10^{6}$ c.f.u. $\mathrm{ml}^{-1}$ as inoculum (Fig. 1b). Additionally, $L$. pneumophila cells with bright fluorescence were observed in free phagosomes outside the protozoan cells. Using CLSM, the limitations of conventional epifluorescence microscopy including out-of-focus haze, could be overcome. Optical sections of the specimen enabled determination of the exact three-dimensional localization of the L. pneumophila cells inside the ciliate. This demonstrated that there were indeed two separate stages of infection, depending on the initial cell concentration. At higher initial cell concentrations, the Legionella remained restricted to small spherical areas, whereas at lower initial cell concentrations they filled nearly the whole lumen of the ciliates. The three-dimensional structure of the $L$. pneumophila cell-cluster within the host cell is elucidated by a collection of four typical optical sections taken at depths of $1 \mu, 3.5 \mu \mathrm{m}, 6 \mu \mathrm{m}$ and $8.5 \mu \mathrm{m}$ (Fig. 2a). The resulting transparent projection of all optical sections in an extended focus image (Fig. 2b) is supplemented by the perpendicular projection (Fig. 2c), which is interpolated from the sections along the optical axis with increments of $0.5 \mu \mathrm{m}$.

\section{DISCUSSION}

The family Legionellaceae includes members which act as pathogens in both humans and protozoa as well as members so far only described as pathogens of amoebae (Rowbotham, 1980, 1993). It is assumed that various freeliving protozoa are the natural hosts for most members of the Legionellaceae and that intracellular growth is a prerequisite or at least an advantage for life in natural water environments (Fields, 1993). Legionella spp. have been shown to preferentially live in biofilms where close interaction with other water micro-organisms is possible
(Henke \& Seidel, 1986; Wadowsky et al., 1988; Fields et al., 1989). However, most of the discussion dealing with the ecology of Legionella spp. is speculative and needs further verification. One tool that could help to further examine the behaviour of Legionella spp. in complex microbial communities and diverse ecosystems is the application of rRNA-targeted oligonucleotide probes, which combine defined specificity with an indication of the physiological state of the detected cell.

The probes developed during this project were specific for most members of the Legionellaceae. In particular, clinically relevant species of the family Legionellaceae, such as $L$. pneumophila, $L$. longbeachae, $L$. micdadei and $L$. bozemanii, tested positive with our probes. Since isolates of Legionellaceae from environmental samples are characterized for the most part as L. pneumophila (Bartlett $e$ t al., 1983; Habicht \& Müller, 1988) the probes are also of great value for ecological studies.

Probes LEG705 and LEG226 also hybridized to S. lyticum, an obligate intracellular parasite closely related to the Legionellaceae (Springer et al., 1992; Rowbotham, 1993). A $16 \mathrm{~S}$ rRNA database comparison revealed that the target sequence of probe LEG705 is also present in M. alba, a methane-oxidizing bacterium. These bacteria occur where both methane and oxygen are present, for example in the water and mud above anaerobic sediments (Hansen, 1980). The value of probe LEG705 for analysis of clinical and drinking water samples is therefore not compromised. As for the specificity of probe LEG226, within the available database which comprises more than 1500 complete or almost complete $16 \mathrm{~S}$ rRNA sequences only members of the family Legionellaceae showed complementarity to the probe sequence. On the other hand, probe LEG226 revealed a somewhat narrower specificity and weaker fluorescent signals during in situ whole-cell hybridizations than probe LEG705.

Specific detection of Legionella spp. in natural environments has so far mainly been done by using antibodies or PCR and related techniques (Fliermans $\mathrm{et}$ al., 1981; Makin \& Hart, 1989; Rogers \& Keevil, 1992; Koide et al., 1993; Palmer et al., 1993). Whole-cell probing with rRNAtargeted oligonucleotides will be an important addition to these established techniques. The use of antibodies in natural samples is often hampered by non-specific binding to other bacteria or even detritus particles. Furthermore, biofilms have been shown to act as penetration barriers for antibodies making detection of cells in deeper layers of biofilms a difficult task (Szwerinski et al., 1985).

In this study, $16 \mathrm{~S}$ rRNA-targeted probes were successfully used to detect Legionella spp. in both natural water samples and model biofilms without non-specific fluorescence. Detection of Legionellaceae with the 16S rRNA probes was also possible on membrane filters without interference from background fluorescence. This combination of techniques could facilitate the rapid detection of Legionella spp. in water samples. It should, however, be considered that for any microscopic method, around $10^{4}$ cells have to be collected on a 1-inch filter in order to detect one cell per microscopic field. Therefore, PCR or culture techniques 
may be more efficient for detecting low levels of contamination.

The value of culture techniques is compromised by the occurrence of viable but non-culturable cells of Legionella spp. which have been demonstrated for various natural, experimental, and industrial systems (Colbourne et al., 1988; Bej et al., 1991; Paszko-Kolva et al., 1992; Miller et al., 1993). Here, oligonucleotide probes were used for the detection of non-culturable $L$. pneumophila cells (as assessed on BCYE agar) in sterilized drinking water after 1 year of incubation. Approximately one third of the cells showed detectable fluorescence signals with the $16 \mathrm{~S}$ rRNA probes. These cells were assumed to be viable but non-culturable whereas the others may be non-viable cells. These results indicated that like PCR or other gene probe techniques (Bej et al., 1991; Paszko-Kovla et al., 1992; Miller et al., 1993) rRNA-targeted oligonucleotide probing can be used to detect non-culturable Legionellaceae. The great advantage of the $16 \mathrm{~S}$ rRNA probes over PCR is that they are not only specific for detection of bacteria but they also give information on the metabolic activity and the spatial distribution of the detected cells. The detection of $L$. pneumophila was possible inside of eukaryotic cells or biofilms by use of fluorescently labelled rRNA probes. Comparable in situ detection is difficult to achieve with antibodies due to the diffusion and penetration barriers.

The application of CLSM allowed the reconstruction of the spatial arrangement of the Legionellaceae inside the protozoan host cells. Similar, yet less detailed observations on the invasion of amoebae and ciliated protozoa by Legionella spp. and the intracellular growth of legionellae have been made previously with conventional techniques (Rowbotham, 1980; Fields, 1993). It has been shown that active phagocytosis is necessary for the uptake of Legionella spp. into amoebae, and single cells of Legionella spp. could be found immediately after entry within a special kind of phagosome, the so-called endosome (Fields, 1993). In this study Legionella spp. could be identified both in defined subcellular compartments and randomly in the cytoplasm. The strong fluorescent signals of the intracellular legionellae reflected a high cellular ribosome content and therefore a high physiological activity. High metabolic activity of the intracellular Legionella spp. has also been shown by Rowbotham (1986), based on the observation of highly motile intracellular Legionella spp. cells in certain stages of infection. Hybridization with the $16 \mathrm{~S}$ rRNA probes also revealed that densely packed aggregates of highly active $L$. pneumophila cells developed in the protozoa and were released by lysis of host cells.

Fluorescent oligonucleotide probes like LEG705 combined with CLSM will in the future help to monitor the spatial and temporal distribution of microbial populations with a resolution that is not possible with conventional techniques. The consequent use of the $16 \mathrm{~S}$ rRNA probes will help to further examine and understand the ecology of micro-organisms with complex growth requirements, such as the members of the Legionellacae. It should be also feasible to elucidate whether, as frequently reported, sudden high contamination of water by Legionella spp. is indeed due to proliferation in protozoa and how other processes like survival and multiplication in biofilms may also contribute to this phenomenon. Furthermore, these probes are quick and easy tools for the detection and identification of Legionella spp. in routine diagnosis.

\section{ACKNOWLEDGEMENTS}

This work was supported by a FEMS fellowship to W.M., a grant from the EC (BIOT-CT-91-0294) to K.H.S. and a grant of the Swedish Water and Wastewater Association (No. 90-116) to U.S. and T.A.S. We like to thank Ingela Blomen for excellent technical assistance and Bernhard $A ß m u s$ for support on CLSM.

\section{REFERENCES}

Amann, R. I., Krumholz, L. \& Stahl, D. A. (1990a). Fluorescent oligonucleotide probing of whole cells for determinative, phylogenetic and environmental studies in microbiology. J Bacteriol 172, 762-770.

Amann, R. I., Binder, B. J., Olson, R. J., Chisholm, S. W., Devereux, R. \& Stahl, D. A. (1990b). Combination of 16S rRNA-targeted oligonucleotide probes with flow cytometry for analyzing mixed microbial populations. Appl Environ Microbiol 56, 1919-1925.

Amann, R. I., Springer, N., Ludwig, W., Gortz, H.-D. \& Schleifer, K.-H. (1991). Identification in situ and phylogeny of uncultured bacterial endosymbionts. Nature 351, 161-164.

Barbaree, J. M., Fields, B. S., Feeley, J. C., Gorman, G. W. \& Martin, W. T. (1986). Isolation of protozoa from water associated with a legionellosis outbreak and demonstration of intracellular multiplication of Legionella pneumophila. Appl Environ Microbiol 51, 422-424.

Bartlett, C. L. R., Kurtz, J. B., Hutchinson, J. G. P. \& Turner, G. C. (1983). Legionella in hospital and hotel water supplies. Lancet ii, 1315.

Bej, A. K., Mahbubani, M. H. \& Atlas, R. M. (1991). Detection of viable Legionella pneumophila in water by polymerase chain reaction and gene probe methods. Appl Environ Microbiol 57, 597-600.

Brenner, D. J., Steigerwalt, A. G. \& McDade, J. E. (1979). Classification of the Legionnaires' disease bacterium: Legionella pneumophila, genus novum, species nova, of the family Legionellaceae, familia nova. Ann Intern Med 90, 656-658.

Brosius, J., Dull, T. L., Sleeter, D. D. \& Noller, H. F. (1981). Gene organization and primary structure of a ribosomal RNA operon from Escherichia coli. J Mol Biol 148, 107-127.

Colbourne, J. S. \& Dennis, P. J. (1989). The ecology and survival of Legionella pneumophila. J Int Water Environ Manage 3, 345-350.

Colbourne, J. S., Dennis, P. J., Trew, R. M., Berry, C. \& Vesey, G. (1988). Legionella and public water supplies. Water Sci Tecbnol 20, 5-10.

DeLong, E. F., Wickham, G. S. \& Pace, N. R. (1989). Phylogenetic stains: ribosomal RNA based probes for the identification of single cells. Science 243, 1360-1363.

Dennis, P. J., Brenner, D. J., Thacker, W. L., Wait, R., Vesey, G., Steigerwalt, A. G. \& Benson, R. F. (1993). Five new Legionella species isolated from water. Int J Syst Bacteriol 43, 329-337.

Dondero, T. J., Jr, Rendtorff, R. C., Mallison, G. F., Weeks, R. M., Levy, J. S., Wong, E. W. \& Schaffner, W. (1980). An outbreak of Legionnaires' disease associated with a contaminated air cooling tower. $N$ Engl J Med 302, 365-370. 
Edelstein, P. H., Beer, K. B., Sturge, J. C., Watson, A. J. \& Goldstein, L. C. (1985). Clinical utility of a monoclonal direct fluorescent reagent specific for Legionella pneumophila: comparative study with other reagents. J Clin Microbiol 22, 419-421.

England, A. C., Fraser, D. W., Mallison, G. F., Mackel, D. C., Skaliy, P. \& Gorman, G. W. (1982). Failure to predict culture results from disinfectant-treated air conditioning cooling towers. Appl Environ Microbiol 43, 240-244.

Fallon, R. J. \& Rowbotham, T. J. (1990). Microbiological investigations into an outbreak of Pontiac fever due to Legionella micdadei associated with use of a whirlpool. J Clin Pathol 43, 479-483.

Fields, B. S. (1993). Legionella and protozoa: interaction of a pathogen and its natural host. In Legionella: Current Status and Emerging Perspectives, pp. 129-136. Edited by J. M. Barbaree, R. F. Breimann \& A. P. Dufour. Washington: American Society for Microbiology.

Fields, B. S., Shotts, E. B., Jr, Feeley, J. C., Gorman, G. W. \& Martin, W. T. (1984). Proliferation of Legionella pneumophila as an intracellular parasite of the ciliated protozoan Tetrabymena pyriformis. Appl Environ Microbiol 47, 467-471.

Fields, B. S., Sanden, G. N., Barbaree, J. M., Morrill, W. E., Wadowsky, R. M., White, E. H. \& Feeley, J. C. (1989). Intracellular multiplication of Legionella pneumophila in amoebae isolated from hospital hot water tanks. Curr Microbiol 18, 131-137.

Fliermans, C. B., Chery, W. B., Orrison, C. H., Tison, D. H. \& Smith, S. J. (1981). Ecological distribution of Legionella pneumophila. Appl Environ Microbiol 41, 9-16.

Fry, N. K., Rowbotham, T. J., Saunders, N. A. \& Embley, T. M. (1991a). Direct amplification and sequencing of the $16 \mathrm{~S}$ ribosomal DNA of an intracellular Legionella species recovered by amoebal enrichment from the sputum of a patient with pneumonia. FEMS Microbiol Lett 83, 165-186.

Fry, N. K., Warwick, S., Saunders, N. A. \& Embley, T. M. (1991b). The use of $16 \mathrm{~S}$ ribosomal RNA analyses to investigate the phylogeny of the family Legionellaceae. J Gen Microbiol 137, 1215-1222.

Gosting, L. H., Cabrian, K., Sturge, J. C. \& Goldstein, L. C. (1984). Identification of a species-specific antigen in Legionella pneumopbila by a monoclonal antibody. J Clin Microbiol 20, 1031-1035.

Grimont, A. D., Grimont, F., Desplaces, N. \& Tchen, P. (1985). DNA probe specific for Legionella pneumophila. J Clin Microbiol 21, 431-437.

Habicht, W. \& Muller, H. E. (1988). Occurrence and parameters of frequency of Legionella in warm water systems of hospitals and hotels in Lower Saxony. Zentralbl Bakteriol Hyg B 186, 79-88.

Hansen, R. S. (1980). Ecology and diversity of methylotrophic organisms. Adv Appl Microbiol 26, 3-39.

Henke, M. \& Seidel, K. M. (1986). Association between Legionella pneumophila and amoebae in water. Isr J Med Sci 22, 690-695.

Hussong, D., Colwell, R. R., O'Brien, M., Weiss, E., Pearson, A. D., Weiner, R. M. \& Burge, W. D. (1987). Viable Legionella pneumophila not detectable by culture on agar media. Bio/Technology 5, 947-950.

Koide, M., Saito, A., Kusano, N. \& Higa, F. (1993). Detection of Legionella spp. in cooling tower water by the polymerase chain reaction method. Appl Environ Microbiol 59, 1943-1946.

Kurtz, J. B., Bartlett, C. L. R., Newton, U. A., White, R. A. \& Jones, N. L. (1982). Legionella pneumophila in cooling water systems report of a survey of cooling towers in London and a pilot trial of selected biocides. J Hyg 88, 369-381.

Larsen, N., Olsen, G. J., Maidak, B. L., McCaughey, M. J., Overbeek, R., Macke, T. J., Marsh, T. L. \& Woese, C. R. (1993). The ribosomal database project. Nucleic Acids Res 21, 3021-3023.
Ludwig, W. \& Stackebrandt, E. (1983). A phylogenetic analysis of Legionella. Arch Microbiol 135, 45-50.

Mahbubani, M. H., Bej, A. K., Miller, R., Haff, L., DiCesare, J. \& Atlas, R. M. (1990). Detection of Legionella with polymerase chain reaction and gene probe methods. Mol Cell Probes 4, 175-187.

Makin, T. \& Hart, C. A. (1989). Detection of Legionella pneumophila in environmental water samples using a fluorescein conjugated monoclonal antibody. Epidemiol Infect 103, 105-112.

Manz, W., Amann, R., Ludwig, W., Wagner, M. \& Schleifer, K.-H. (1992). Phylogenetic oligodeoxynucleotide probes for the major subclasses of proteobacteria: problems and solutions. Syst Appl Microbiol 15, 593-600.

Manz, W., Szewzyk, U., Eriksson, P., Amann, R., Schleifer, K.-H. \& Stenström, T.-A. (1993). In situ identification of bacteria in drinking water and adjoining biofilms by hybridization with $16 \mathrm{~S}$ and $23 \mathrm{~S}$ rRNA-directed fluorescent oligonucleotide probes. Appl Environ Microbiol 59, 2293-2298.

Miller, L. A., Beebe, J. L., Butler, J. C., Martin, W., Benson, R., Hoffman, R. E. \& Fields, B. S. (1993). Use of polymerase chain reaction in an epidemiologic investigation of Pontiac fever. I Infect Dis 168, 769-772.

Neef, J. M., Vandepeer, Y., DeRijk, P., Chapelle, S. \& DeWachter, R. (1993). Compilation of small ribosomal subunit RNA structures. Nucleic Acids Res 21, 3025-3049.

Palmer, C. J., Tsai, Y.-L., Paszko-Kolva, C., Mayer, C. \& Sangermano, L. R. (1993). Detection of Legionella species in sewage and ocean water by polymerase chain reaction, direct fluorescentantibody, and plate culture methods. Appl Environ Microbiol 59, 3618-3624.

Paszko-Kolva, C., Shahamat, M. \& Colwell, R. R. (1992). Longterm survival of Legionella pneumophila serogroup 1 under lownutrient conditions and associated morphological changes. FEMS Microbiol Ecol 102, 45-55.

Ramsing, N. B., Kuhl, M. \& Jørgensen, B. B. (1994). Distribution of sulfate-reducing bacteria, $\mathrm{O}_{2}$, and $\mathrm{H}_{2} \mathrm{~S}$ in photosynthetic biofilms determined by oligonucleotide probes and microelectrodes. Appl Environ Microbiol 59, 3840-3849.

Rogers, J. \& Keevil, C. W. (1992). Immunogold and fluorescein immunolabelling of Legionella pneumophila within an aquatic biofilm visualized by using episcopic differential interference contrast microscopy. Appl Environ Microbiol 58, 2326-2330.

Rowbotham, T. J. (1980). Preliminary report on the pathogenicity of Legionella pneumophila for freshwater and soil amoebae. J Clin Patbol 33, 1179-1183.

Rowbotham, T. J. (1983). Isolation of Legionella pneumophila from clinical specimens via amoebae, and the interactions of those and other isolates with amoebae. J Clin Patbol 36, 978-986.

Rowbotham, T. J. (1986). Current views on the relationship between amoebae, legionellae and man. Isr J Med Sci 22, 678-689.

Rowbotham, T. J. (1993). Legionella-like amoebal pathogens. In Legionella: Current Status and Emerging Perspectives, pp. 137-140. Edited by J. M. Barbaree, R. F. Breimann \& A. P. Dufour. Washington: American Society for Microbiology.

Schleifer, K. H. \& Ludwig, W. (1989). Phylogenetic relationships among bacteria. In The Hierarchy of Life, pp. 103-117. Edited by B. Fernholm, K. Brenner \& H. Jörnvall. Amsterdam: Elsevier Science Publishers.

Springer, N., Ludwig, W., Drozanski, W., Amann, R. \& Schleifer, K.-H. (1992). The phylogenetic status of Sarcobium lyticum, an obligate intracellular bacterial parasite of small amoebae. FEMS Microbiol Lett 96, 199-202.

Stahl, D. A. \& Amann, R. I. (1991). Development and application of 
nucleic acid probes in bacterial systematics. In Sequencing and Hybridization Techniques in Bacterial Systematics, pp. 205-248. Edited by E. Stakebrandt \& M. Goodfellow. Chichester: John Wiley and Sons.

Starnbach, M. N., Falkow, S. \& Tompkins, L. S. (1989). Speciesspecific detection of Legionella pneumophila in water by DNA amplification and hybridization. J Clin Microbiol 27, 1257-1261.

States, S. J., Wadowsky, R. M., Kuchta, J. M., Wolford, R. S., Conley, L. F. \& Yee, R. B. (1990). Legionella in drinking water. In Drinking Water Microbiology, pp. 340-367. Edited by G. A. McFeters. New York: Springer-Verlag.

Szewzyk, U., Manz, W., Amann, R., Schleifer, K.-H. \& Stenström, T.-A. (1994). Growth and in situ detection of a pathogenic Escherichia coli in biofilms of a heterotrophic water-bacterium by use of 16S- and 23S-rRNA-directed fluorescent oligonucleotide probes. FEMS Microbiol Ecol 13, 169-176.

Szwerinski, H., Gaiser, S. \& Bardtke, D. (1985). Immunofluorescence for the quantitative determination of nitrifying bacteria: interference of the test in biofilm reactors. Appl Microbiol Biotechnol 21, 125-128.
Wadowsky, R. M., Butler, L. J., Cook, M. K., Verma, S. M., Paul, M. A., Fields, B. S., Keleti, G., Sykora, J. L. \& Yee, R. B. (1988). Growth-supporting activity for Legionella pneumophila in tap water cultures and implication of Hartmannellid amoebae as growth factors. Appl Environ Microbiol 54, 2677-2682.

Wagner, M., Amann, R., Lemmer, H. \& Schleifer, K.-H. (1993). Probing activated sludge with oligonucleotides specific for Proteobacteria: inadequacy of culture-dependent methods for describing microbial community structure. Appl Environ Microbiol 59, 1520-1525.

Winn, W. C. (1988). Legionnaire's disease: a historical perspective. Clin Microbiol Rev 1, 60-81.

Zarda, B., Amann, R., Wallner, G. \& Schleifer, K.-H. (1991). Identification of single bacterial cells using digoxigenin-labelled, rRNA-targeted oligonucleotides. J Gen Microbiol 137, 2823-2830.

Received 9 June 1994; revised 20 September 1994; accepted 6 October 1994. 